THE WORLD BANK ECONOMIC REVIEW, VOL. 14, NO. 3: $415-43$

\title{
Can Africa's Saving Collapse Be Reversed?
}

\author{
Ibrahim A. Elbadawi and Francis M. Mwega
}

\begin{abstract}
Private saving in Sub-Saharan Africa declined from more than 11 percent of disposable income in the 1970s to less than 8 percent in the 1980s and only partially recovered (to less than 9 percent) in the 1990s. This article analyzes the determinants of private saving in Sub-Saharan Africa, seeking to explain the region's dismal performance and identify policies that could help to reverse the region's decline in saving. The analysis shows that in Sub-Saharan Africa causality runs from growth to investment (and perhaps to private saving), whereas a rise in the saving rate Granger-causes an increase in investment. Foreign aid Granger-causes a reduction in both saving and investment, and investment also Granger-causes an increase in foreign aid. The empirical analysis of private saving in SubSaharan Africa and other regions over 1970-95 suggests that private saving in Africa can be explained by standard behavioral models. According to these models private saving in Africa lags behind that in other regions (most notably, the high performing Asian economies) becouse of the region's lower per capita income, high young-age dependency ratio, and bigh dependence on aid. The combined effects of these factors substantially outweigh Africa's advantage from its lower public saving and higher government consumption. Finally, analysis of the experiences of Kenya, Zimbabwe, and Botswana provides further insight into the saving process in Sub-Saharan Africa.
\end{abstract}

Sub-Saharan Africa's growth and overall economic performance over the past two decades have been described in recent scholarly writings as "tragic" (Easterly and Levine 1997) and of "crisis proportions" (Elbadawi and Ndulu 1996). ${ }^{1}$ Unfortunately, these assessments are not exaggerations. The median annual growth rate of real gross domestic product (GDP) per capita in Africa declined steadily from more than 2.0 percent in the 1970 s to -0.3 percent in $1980 \mathrm{~s}$ and to -1.3 percent in the 1990s. Over that period Africa's growth performance also lagged considerably relative to that of other regions, most notably the high-performing Asian economies. After noting that in 1996 Sub-Saharan Africa registered its highest economic growth in two decades (total income grew at 5 percent), Rodrik (1997:1) cautions, "The sobering reality is that it will take many years of growth

1. See also Collier (1995), Rodrik (1997), Schmidt-Hebbel (1996), and Hadjimichael and Ghura (1995), among others.

Ibrahim A. Elbadawi is with the Development Research Group and the Africa Region at the World Bank, and Francis M. Mwega is with the Department of Economics at the University of Nairobi. Their email addresses are ielbadawi@worldbank.org and aercres@form-net.com. This article was prepared for the World Bank's project, "Saving Across the World: Puzzles and Policies." The authors would like to acknowledge the research assistance of Radha Ruparel. They also are grateful to the editor of The World Bank Economic Review and two anonymous referees for helpful comments.

- 2000 The International Bank for Reconstruction and Development / THE wORLD BANK 
at such levels (or better) to undo the damage that more than two decades of stagnation and decline have inflicted on most countries of the region."

Growth rates in Sub-Saharan Africa and other regions have been strongly associated with their private saving and investment rates. For example, private saving in Sub-Saharan Africa declined from 11.4 percent of disposable income in the 1970 s to only 7.5 percent in the 1980 s. It only partially recovered to less than 9 percent in the 1990s. In addition, public saving in Sub-Saharan Africa has remained low-at less than 3 percent of disposable income in the 1990s, declining from 4.3 percent in the 1980 s. The slowdown in gross domestic investment (as a fraction of GDP) has been equally dramatic: it declined steadily from 21 percent in the 1970s to about 17 percent in the 1990s.

Like growth, saving and investment In Sub-Saharan Africa lagged behind that in all other regions, especially the high-performing Asian economies. ${ }^{3}$ The Asian economies had private saving (and investment) rates that were almost 10 percent of GDP (or almost 17 percent of disposable income) higher than those of Sub-Saharan Africa. Moreover, saving in Sub-Saharan Africa was not only lower relative to other regions but also less stable. For example, the coefficient of variation of private (public) saving in Sub-Saharan Africa is more than three (two) times that of the high-performing Asian economies. Yet another worrisome feature of saving and investment in Sub-Saharan Africa is the region's heavy dependence on foreign saving, mostly overseas development assistance, to finance the gap between investment and saving, which averaged slightly less than 11 percent of GDP in 1970-95. This contrasts sharply with the high-performing Asian economies, where saving exceeded investment by 2.6 and 3.4 percent in $1970-79$ and 1980-89, respectively, and was virtually equal to investment in 1990-95 (tables 1 and 2).

The urgent need to reinvigorate and sustain growth in the developing world has inspired a plethora of theoretical frameworks aimed at understanding the observed empirical correlations among growth, saving, and investment, as well as their determinants. Although researchers have made good progress on the empirical modeling of growth and investment in Sub-Saharan Africa and other developing regions, the variation of private saving across countries and over time is less understood (Schmidt-Hebbel, Servén, and Solimano 1994, 1996).4 The presence of significant and negative dummy variables for Africa and Latin America in cross-country regressions of private saving underscores this point (see, for example, Edwards 1995 and Mwega 1996).

Schmidt-Hebbel, Servén, and Solimano (1996) review several theories on the direction of causation between saving and growth, ranging from the classical

2. According to Rodrik (1997) roughly a third of the countries in Sub-Saharan Africa (16 countries in all) had higher per capita GDP in the early $1960 \mathrm{~s}$ than they do three and a half decades later.

3. We include in this category China, Hong Kong, Indonesia, the Republic of Korea, Malaysia, Singapore, Taiwan (China), and Thailand.

4. Easterly and Levine (1997); Schmidt-Hebbel (1996); Elbadawi, Ndulu, and Ndung'u (1997); and Collier (1998) estimate endogenous growth models with a focus on Sub-Saharan Africa. Empirical investment models that emphasize risk and the irreversibility of investment include Serven (1997); Elbadawi, Ndulu, and Ndung'u (1997); and Collier (1998). 
Table 1. Saving and Investment in Sub-Saharan Africa and the High-Performing Asian Economies, 1970-95 (percent)

\begin{tabular}{|c|c|c|c|c|c|c|}
\hline \multirow[b]{2}{*}{ Years } & \multicolumn{3}{|c|}{ Sub-Saharan Africat } & \multicolumn{3}{|c|}{ High-performing Asian economies } \\
\hline & $\begin{array}{c}\text { Ratio of gross } \\
\text { domestic savings } \\
\text { to gross domestic } \\
\text { product }\end{array}$ & $\begin{array}{l}\text { Ratio of gross } \\
\text { domestic } \\
\text { investment to } \\
\text { gross domestic } \\
\text { product }\end{array}$ & $\begin{array}{l}\text { Investment- } \\
\text { saving gap }\end{array}$ & $\begin{array}{c}\text { Ratio of gross } \\
\text { domestic savings } \\
\text { to grass domestic } \\
\text { product }\end{array}$ & $\begin{array}{c}\text { Ratio of gross } \\
\text { domestic } \\
\text { investment to } \\
\text { gross domestic } \\
\text { product }\end{array}$ & $\begin{array}{l}\text { Investment- } \\
\text { saving gap }\end{array}$ \\
\hline $1970-79$ & 11.72 & 21.37 & 9.65 & 29.17 & 26.52 & -2.65 \\
\hline $1980-89$ & 6.66 & 18.69 & 12.03 & 33.24 & 29.84 & -3.40 \\
\hline $1990-95$ & 6.24 & 17.19 & 10.95 & 35.65 & 36.46 & 0.81 \\
\hline
\end{tabular}

a. Sub-Saharan Africa includes Angola, Benin, Botswana, Burkina Faso, Burundi, Cameroon, Central African Republic, Chad, Comoros, Congo, Cóte d'lvoire, Diibouti, Ethiopia, Gabon, The Gambia, Ghana, Guinea, Guinea Bissau, Kenya, Lesotho, Liberia, Madagascar, Malawi, Mali, Mauritania, Mauritius, Mozambique, Namibia, Niger, Nigeria, Rwanda, São Tomé and Principe, Senegal, Seychelles, Sierra Leone, South Africa, Sudan, Swaziland, Tanzania, Togo, Uganda, Zambia, and Zimbabwe.

b. The high-performing Asian economies include China, Hong Kong, Indonesia, the Republic of Korea, Malaysia, Singapore, Taiwan (China), snd Thailand. Source: Authors' calculations based on data in the World Bank's World Saving Database. 
Table 2. Aid Dependence in Sub-Saharan Africa and Other Developing Regions, 1970-95

(percent)

\begin{tabular}{lcccc} 
Indicator & $\begin{array}{c}\text { Sub- } \\
\text { Saharan } \\
\text { Africat }\end{array}$ & $\begin{array}{c}\text { High- } \\
\text { performing } \\
\text { Asian economies }\end{array}$ & $\begin{array}{c}\text { Sowth } \\
\text { Asiac }\end{array}$ & $\begin{array}{c}\text { Latin } \\
\text { America and } \\
\text { the Caribbeand }\end{array}$ \\
\hline $\begin{array}{l}\text { Median percentage of years for } \\
\text { which the ratio of aid to gross } \\
\text { domestic product is greater } \\
\text { than 10 percent }\end{array}$ & 60.87 & 0.00 & 0.00 & 0.00 \\
$\begin{array}{l}\text { Mean percentage of years for } \\
\text { which the ratio of aid to gross } \\
\text { domestic product is greater } \\
\text { than } 10 \text { percent }\end{array}$ & 47.57 & 0.00 & 18.09 & 6.56 \\
\hline
\end{tabular}

a. Sub-Saharan Africa includes Angola, Benin, Botswana, Burkina Faso, Burundi, Cameroon, Central African Republic, Chad, Comoros, Congo, Cóte d'Ivoire, Djibouti, Ethiopia, Gabon, The Gambia, Ghana, Guinea, Guinea Bissau, Kenya, Lesotho, Liberia, Madagascar, Malawi, Mali, Mauritania, Mauritius, Mozambique, Namibia, Niget, Nigeria, Rwanda, Såo Tomé and Principe, Senegal, Seychelles, Sierra Leone, South Africa, Sudan, Swaziland, Tanzania, Togo, Uganda, Zambia, and Zimbabwe.

b. The high-performing Asian economies include China, Hong Kong, Indonesia, the Republic of Korea, Malaysia, Singapore, Taiwan (China), and Thailand.

c. South Asia includes Bangladesh, Bhutan, Cook Island, India, Maldives, Myanmar, Nepal, Pakistan, and Sri Lanka.

d. Latin America and the Caribbean includes Antigua and Barbuda, Argentina, the Bahamas, Barbados, Belize, Bolivia, Brazil, Chile, Colombia, Costa Rica, Dominica, Dominican Republic, Ecuador, El Salvador, Grenada, Guatemala, Guyana, Haiti, Honduras, Jamaica, Mexico, Nicaragua, Panama, Paraguay, Peru, St. Kitts and Nevis, St. Lucia, St. Vincent and the Grenadines, Suriname, Trinidad and Tobago, Uruguay, and Veneruela.

Source: Authors' calculations based cn data in the World Bank's World Saving Database.

permanent-income and life-cycle hypotheses to more recent and less conventional models. The newer models-which emphasize slowly changing consumption habits (Carroll, Overland, and Weil 1995), a mixture of strong consumption habits with uncertain incomes (Carroll and Weil 1993), or the presence of consumers who value both consumption and wealth (Cole, Mailath, and Postlewaite 1992; Fershtman and Weiss 1993; and Zou 1993)-broadly suggest that growth drives saving. Moreover, they argue that even when saving is assumed to translate automatically into capital accumulation and hence growth, failure to account for reverse causation from growth to saving is likely to overstate the contribution of saving to growth (Carroll and Weil 1993).

At the empirical level, however, the evidence on causation from growth to saving is not conclusive (Schmidt-Hebbel, Servén, and Solimano 1996). The analysis of private saving in Sub-Saharan Africa remains of immense policy importance even though growth in Sub-Saharan Africa has been shown to drive both saving and investment. Admittedly, if we assume that growth drives saving, then policies aimed at directly promoting growth (such as technological innovation or further development of human capital) should be the prime focus of attention. However, policies for directly promoting private saving may still be important for at least three reasons. First, even though capital accumulation may follow 
rather than lead growth, international evidence-most notably the experiences of the high-performing Asian economies-suggests that sustaining high rates of growth requires substantial physical capital accumulation. Second, to the extent that Sub-Saharan Africa faces binding lending constraints in international capital markets or concessional development finance, national saving will drive aggregate investment (Summers 1988), and hence saving will influence the sustainability of growth. Third, the recent experiences of Mexico and Chile, for example, have shown that high national saving is a prerequisite for avoiding financial crises and the subsequent collapse of growth (Williamson 1997). ${ }^{s}$

In this article we analyze the determinants of private saving in Sub-Saharan Africa to explain the region's dismal saving behavior and to identify policies that could help to reverse its decline in saving. Although raising the saving rate is not sufficient for achieving sustained growth, it does appear to be necessary. In fact, identifying policies that promote saving (and the policy distortions that inhibit saving) should be an essential element in any strategy aimed at making SubSaharan Africa less dependent on aid, given the extent of its dependence and the anticipated global reduction in foreign aid.

\section{Causaltiy among Saving, Investment, Growth, and Foreign Aid in SUB-SAHARAN AFRICA}

In this section we establish the causal links among saving, investment, growth, and foreign aid, taking into account their dynamic relationships (see, for example, Carroll and Weil 1993). Traditional analyses of these relationships have focused on the links between domestic saving and investment, the effects of saving and investment on economic growth, and, more recently, the impact of foreign aid.

\section{The Relationship between Saving and Investment}

The first issue is whether domestic saving and investment are strongly correlated. In an open economy an increase in domestic saving need not translate into an increase in domestic investment. With complete capital mobility, investment and saving could be independent of one another. With full limitations on capital mobility, domestic saving is translated directly into investment. The extent of the correlation between saving and investment is therefore an empirical matter.

Empirical studies often find that domestic saving is highly correlated with investment (Feldstein and Horioka 1980, Feldstein and Bacchetta 1991, and Bosworth 1993). Researchers have proposed many reasons for this high correlation: productivity and other shocks affect both desired saving and desired investment in the same direction, even if capital is perfectly mobile across countries; an increase in domestic saving induces an increase in investment, particularly in

S. The recent East Asian experience, however, suggests that avoiding financial crises requires more than just attaining high national savings rates. 
large countries; capital controls protect the domestic tax base and the balance of payments; high transaction costs to purchasing securities and investing abroad, fears of expropriation, exchange rate risks, and asymmetric information among countries handicap foreign investors; and access to external credit markets is limited (Gordon and Bovenberg 1994). In Sub-Saharan Africa the gap between saving and investment has been growing since the 1960s.

\section{The Relationship between Growth and Saving and Growth and Investment}

A second question is whether economic growth follows saving and investment or whether saving and investment follow growth. Neoclassical models such as Solow (1956) suggest that an increase in the saving rate generates higher growth only in the short run, during the transition between steady states. The long-run equilibrium rate of growth is exclusively a function of technological progress and growth of the labor force, both assumed to be exogenous. Models based on theories of endogenous growth pioneered by Roemer (1986) and Lucas (1988), however, predict that higher saving and investment rates can permanently raise growth rates. With endogenous technological progress and the accumulation of human capital, saving and investment will increase growth in the steady state. More recent research (for example, Levine and Renelt 1992, De Long and Summers 1993, Easterly and Rebelo 1993, and King and Levine 1994) finds that the investment rate is one of the most important determinants of economic growth. Moreover, other studies using neoclassical production function analysis find that investment, not technological progress, was the main factor behind Southeast Asia's exemplary growth (see, for example, Young 1994). The main argument behind these results is that investment increases the amount of physical capital per worker and therefore raises productivity.

The saving literature suggests that economic growth increases the income of workers relative to that of nonworkers (children and retirees). Hence workers' saving could rise, for example, to allow for increased consumption during retirement. However, children may borrow against future income, and workers, anticipating increased growth, may reduce saving (Tobin 1967 and Bosworth 1993). Growth also may reduce liquidity and borrowing constraints, inducing households to increase consumption. Therefore, economic growth will increase saving if growth is concentrated among households with high saving rates and persistent, strong habits and if consumption adjusts with a lag to an increase in income, especially if the increase is not anticipated. Also, if income is uncertain, income growth could be positively correlated with saving through a precautionary (buffer-stock) motive (Harrigan 1995). Under the permanent-income hypothesis unexpected income will largely be saved.

Causation is two-way if saving also increases growth. A virtuous cycle results as growth leads to more saving, which in turn enhances growth. It is important to determine which direction of causality is dominant: is rapid growth mainly the result of a higher saving rate, or does saving respond mainly to economic growth? If saving is a major determinant of growth, increasing it would be central to policy, whereas if the converse is true, policy should focus largely on the factors 
driving growth (Schmidt-Hebbel and Servén 1996). The most definitive empirical work on this issue is Carroll and Weil (1993). Using causality tests, they find that growth mainly causes changes in saving rates. Perhaps inspired by this result, the Africa adjustment study (World Bank 1994), which notes that saving rates traditionally have been low in Sub-Saharan Africa and have been affected little by adjustment, postulates that saving largely follows economic growth. Even though the study does not conduct a formal causality analysis, it concludes that policymakers in Sub-Saharan Africa should not attempt to force up the saving rate directly; rather, they should establish an environment that facilitates rapid accumulation, efficient resource use, and high productivity growth. Therefore, a formal test of causality among growth, saving, investment, and foreign aid is warranted.

\section{Testing for Causality}

The variables we use to establish the direction of bivariate causality are gross national saving as a proportion of national disposable income (SY), gross domestic investment as a proportion of GDP (IY), real GDP growth $(G R)$, and foreign aid as a proportion of GDP (AIDY). The correlation coefficient between saving and growth $(0.247)$ is slightly higher than that between investment and growth $(0.231)$. However, the strongest link is between saving and investment $(0.532)$. The correlation coefficient is lowest between investment and foreign aid (0.166) and is negative with respect to both saving and growth $(-0.215$ and -0.008$)$.

For each relationship we determine whether variable $X$ significantly adds to the explanation of variable $Y$, controlling for the history of $Y$ (and vice versa) based on the following equations:

$$
\begin{aligned}
& Y_{t, i}=\alpha_{0, i}^{y}+\sum_{j=1}^{n} \alpha_{t-i, i}^{y} Y_{t-j, i}+\sum_{j=1}^{m} \beta_{t-j, i}^{y} X_{t-i, i}+\varepsilon_{t, i}^{y} \\
& X_{t, i}=\alpha_{0, i}^{x}+\sum_{j=1}^{n} \alpha_{t-j, i}^{x} X_{t-j, i}+\sum_{j=1}^{m} \beta_{t-j, i}^{x} Y_{t-j, i}+\varepsilon_{t, i}^{x}
\end{aligned}
$$

wive $i$ refers to the country, and $n$ and $m$ to the number of lags. We estimate these equations using annual data, which allows us to differentiate between shortrun and long-run causality. Rather than experiment with different lag structures for every equation, we use four lags.

One problem with panel data estimation is that differences among countries may reflect country-specific characteristics-such as the efficiency of government, the degree of corruption, the level of violence, or the attitude of the government and population toward individual achievement or enterprise-that jointly influence saving, investment, economic growth, and dependence on foreign aid (Carroll and Weil 1993). Since some of these country-specific effects are difficult to quantify and are likely to be correlated with other observed explanatory variables, fixed-effects estimation is commonly used to control for country-specific variables. The success of this framework depends crucially on the extent to which the 
nonparametric proxies (dummy variables) for fixed effects adequately capture the idiosyncratic aspects of country behavior, such as culture and development aspirations, that cannot be easily observed or measured (Harrigan 1995). Fixed effects estimation in effect eliminates differences across countries, leaving only time-series variations to be explained.

We present both the pooled and the fixed-effects results for the sample of SubSaharan African countries in the World Bank's World Saving Database (tables 3, 4 , and 5). The pooled results are less robust, with only causality from economic growth to investment being significant. We therefore focus on the significant fixed-effects results. ${ }^{6}$

The fixed-effects results show that the saving rate significantly Granger-causes the investment rate (table 3). The effect of the saving rate is persistent, increasing the aggregate coefficient from 0.13 in the short run to 0.37 in the long run. As in the pooled results, the fixed-effects results show significant (at the 5 percent level) and positive causality from economic growth to the investment rate (table 4). The effect of growth on the investment rate is also persistent, increasing the aggregate coefficient from 0.14 in the short run to 0.48 in the long run. Both of these results suggest that the data can be viewed either through neoclassical glasses or with an accelerator model in mind.

Except for the finding that Granger-causality from economic growth to the saving rate is not significant, these results are largely consistent with those derived by Attanasio, Picci, and Scorcu (2000) in their analysis of several groupings of countries. They are also, to some extent, supported by results from South Asia and Latin America and the Caribbean (table 6). In both South Asia and Latin America and the Caribbean the investment rate significantly Granger-causes a reduction in economic growth (at least in the short run). This counterintuitive result may suggest that aggregate investment was driven by public investment, since many countries reduced their growth rates with a public investment boom.

Although there are significant effects from economic growth to investment in both South Asia and Latin America and the Caribbean (as in Sub-Saharan Africa), the effects from economic growth to saving are significant only in Latin America. The saving rate Granger-causes an increase in the investment rate in Latin America and the Caribbean (as in Sub-Saharan Africa), but not in South Asia. Unlike in Sub-Saharan Africa, there are significant effects from the investment rate to the saving rate in both regions, at least in the short run.

6. Another way to control for fixed effects is by differencing the data. This, however, creates movingaverage disturbances that are correlated with the (once) lagged dependent variables. We therefore instrument these variables using the generalized methods of moments (GMM) estimator. Instrumenting the (once) lagged dependent variables also accounts for the endogeneity of $X$ and $Y$ in the two estimation equations. We use internal instruments (lagged values of the explanatory variables) as proposed by HoltzEakin, Newey, and Rosen (1988) and Allerano and Bond (1991), who suggest that one can use the orthogonal restrictions implied in the data dynamics to achieve efficiency if the error terms are serially uncorrelated. Differencing the data, however, and instrumenting the (once) lagged dependent variables give less precise estimates, with none of the relations between the savings rate, investment rate, economic growth; and foreign aid significant at even the 10 percent level. 
Table 3. Causality among Saving, Investment, and Economic Growth in SubSaharan Africa, 1970-95

\begin{tabular}{|c|c|c|c|c|}
\hline Model & $\begin{array}{l}\text { Saving } \rightarrow \\
\text { investment }\end{array}$ & $\begin{array}{l}\text { Investment } \rightarrow \\
\text { saving }\end{array}$ & $\begin{array}{l}\text { Growth } \rightarrow \\
\text { saving }\end{array}$ & $\begin{array}{c}\text { Saving } \rightarrow \\
\text { growth }\end{array}$ \\
\hline \multicolumn{5}{|l|}{ Pooled model } \\
\hline Sum of coefficients & $\begin{array}{c}0.0165 \\
(0.8861)\end{array}$ & $\begin{array}{c}0.0832 \\
(0.9156)\end{array}$ & $\begin{array}{c}0.0635 \\
(0.9718)\end{array}$ & $\begin{array}{c}0.0356 \\
(0.9700)\end{array}$ \\
\hline Long-run coefficients & $\begin{array}{c}0.2243 \\
(0.9111)\end{array}$ & $\begin{array}{c}0.4674 \\
(0.9515)\end{array}$ & $\begin{array}{c}0.4770 \\
(0.9820)\end{array}$ & $\begin{array}{c}0.0388 \\
(0.9544)\end{array}$ \\
\hline Sample size & 693 & 690 & 629 & 638 \\
\hline \multicolumn{5}{|l|}{ Fixed-effects model } \\
\hline Sum of coefficients & $\begin{array}{c}0.1300 \\
(0.0010)\end{array}$ & $\begin{array}{c}0.0419 \\
(0.3800)\end{array}$ & $\begin{array}{c}0.0543 \\
(0.4810)\end{array}$ & $\begin{array}{c}0.0050 \\
(0.9060)\end{array}$ \\
\hline Long-run coefficients & $\begin{array}{c}0.3654 \\
(0.0002)\end{array}$ & $\begin{array}{c}0.1030 \\
(0.3710)\end{array}$ & $\begin{array}{c}0.1191 \\
(0.4700)\end{array}$ & $\begin{array}{c}0.0050 \\
(0.9060)\end{array}$ \\
\hline Sample size & 693 & 690 & 629 & 638 \\
\hline
\end{tabular}

Note: Sum is the sum of the Granger-causality coefficients in the estimation equations. The long-run coefficient is derived by dividing this sum by 1 minus the sum of the coefficients of the lagged dependent variables. The numbers in parentheses are $p$-values. The $p$-value is the probability that the sum of the estimated Granger-causality coefficients is equal to zero.

Source: Authors' calculations based on data in the World Bank's World Saving Database.

The fixed-effects results for Sub-Saharan Africa also show that the foreign aid ratio significantly Granger-causes a reduction in the saving rate, as expected from the permanent-income hypothesis, provided that aid is not entirely wasted (table 4). There is no significant bivariate relationship between aid and growth in the long run, as the Solow model predicts.

Lastly, the fixed-effects. results show that the foreign aid ratio and the investment rate Granger-cause one another, at least at the 10 percent level (table 5). The foreign aid ratio reduces investment, while the investment rate raises the foreign aid ratio. The latter suggests that African countries that increase investment receive more foreign aid.

A literal interpretation of the fixed-effects results is that, although the saving rate increases the investment rate, neither variable is relevant for initiating and sustaining growth in Sub-Saharan Africa. However, domestic saving is still likely to be critical not only for increasing investment finance but also for promoting economic growth. Also, avoiding a large gap between investment and saving contributes to macroeconomic stability and hence economic growth. It thus is important to understand the factors that influence the evolution of saving rates in Sub-Saharan Africa over time and the evolution of saving rates across countries.

\section{Determinants of Private Saving in Sub-Saharan Africa AND IN OTHER REGIONS}

The empirical analysis of private saving is based on a general functional form, encompassing a wide range of theoretical models derived from first principles. 
Table 4. Causality between Investment and Economic Growth and between Foreign Aid and Saving in Sub-Saharan Africa, 1979-95

\begin{tabular}{|c|c|c|c|c|}
\hline Model & Investment $\rightarrow$ growth & Growth-investment & Foreign aid $\rightarrow$ saving & Saving-fforeign aid \\
\hline \multicolumn{5}{|l|}{ Pooled model } \\
\hline \multirow[t]{2}{*}{ Sum of coefficients } & 0.054982 & 0.9195 & -0.0259 & -0.0984 \\
\hline & $(0.8987)$ & $(0.0000)$ & (0.9999) & $(0.9999)$ \\
\hline \multirow[t]{2}{*}{ Long-run coefficient } & 0.0584 & 0.9892 & -0.1660 & -0.9406 \\
\hline & $(0.9545)$ & $(0.7637)$ & $(0.9941)$ & $\{0.9999\}$ \\
\hline Sample size & 679 & 674 & 577 & 596 \\
\hline \multicolumn{5}{|l|}{ Fixed-effects model } \\
\hline \multirow[t]{2}{*}{ Sum of coefficients } & -0.0363 & 0.1433 & -0.0073 & 0.3883 \\
\hline & $(0.428)$ & $(0.037)$ & $(0.014)$ & $(0.753)$ \\
\hline \multirow[t]{2}{*}{ Long-run coefficient } & 313 & 0.4842 & -0.0139 & 0.5777 \\
\hline & $(0.435)$ & $(0.031)$ & $(0.018)$ & $(0.753)$ \\
\hline Sample size & 679 & 674 & 577 & 596 \\
\hline
\end{tabular}

Note: Sum is the sum of the Granger-causality coefficients in the estimation equations. The long-run coefficient is.derived by dividing this sum by 1 minus the sum of the coefficients of the lagged dependent variablea. The numbers in parentheses are p-values. The p-value is the probability that the sum of the estimated Granger-causality coefficients is equal to zero.

Source: Authors' calculations based on data in the World Bank's World Saving Database. 
Table 5. Causality between Foreign Aid and Growth and Foreign Aid and Investment in Sub-Saharan Africa, 1979-95

\begin{tabular}{|c|c|c|c|c|}
\hline Model & $\begin{array}{l}\text { Foreign aid } \rightarrow \text { gross } \\
\text { domestic investment }\end{array}$ & $\begin{array}{c}\text { Gross domestic investment } \rightarrow \\
\text { foreign aid }\end{array}$ & Foreign aid $\rightarrow$ growth & $\begin{array}{l}\text { Growth } \rightarrow \\
\text { foreign aid }\end{array}$ \\
\hline \multicolumn{5}{|l|}{ Pooled model } \\
\hline Sum of coefficients & $\begin{array}{c}0.0067 \\
(0.9999)\end{array}$ & $\begin{array}{c}0.1939 \\
(0.9999)\end{array}$ & $\begin{array}{c}0.0031 \\
(0.9999)\end{array}$ & $\begin{array}{l}-0.1673 \\
(0.9999)\end{array}$ \\
\hline Long-run coefficient & $\begin{array}{c}0.1510 \\
(0.9999)\end{array}$ & $\begin{array}{c}0.9336 \\
(0.9999)\end{array}$ & $\begin{array}{c}0.0039 \\
(0.9999)\end{array}$ & $\begin{array}{c}-1.1164 \\
(0.9999)\end{array}$ \\
\hline Sample size & 612 & 619 & 608 & 607 \\
\hline \multicolumn{5}{|l|}{ Fixed-effects model } \\
\hline Sum of coefficients & $\begin{array}{c}-0.0263 \\
(0.087)\end{array}$ & $\begin{array}{c}0.3802 \\
(0.020)\end{array}$ & $\begin{array}{c}0.0142 \\
(0.431)\end{array}$ & $\begin{array}{c}-0.3450 \\
(0.266)\end{array}$ \\
\hline Long-run coefficient & $\begin{array}{c}-0.0909 \\
(0.101)\end{array}$ & $\begin{array}{c}0.6055 \\
(0.0221)\end{array}$ & $\begin{array}{c}0.0132 \\
(0.435)\end{array}$ & $\begin{array}{c}0.5446 \\
(0.264)\end{array}$ \\
\hline Sample size & 612 & 619 & 608 & 607 \\
\hline
\end{tabular}

Note: Sum is the sum of the Granger-causality coefficients in the estimation equations. The long-run coefficient is derived by dividing this sum by 1 minus the sum of the coefficients of the lagged dependent variables. The numbers in parentheses are $p$-values. The $p$-value is the probability that the sum of the estimated Granger-causality coefficients is equal to zero.

Source: Authors' calculations based on data in the World Bank's World Saving Database. 
Table 6. Fixed-Effects Granger Causality Results for South Asia and Latin America and the Caribbean, 1970-95

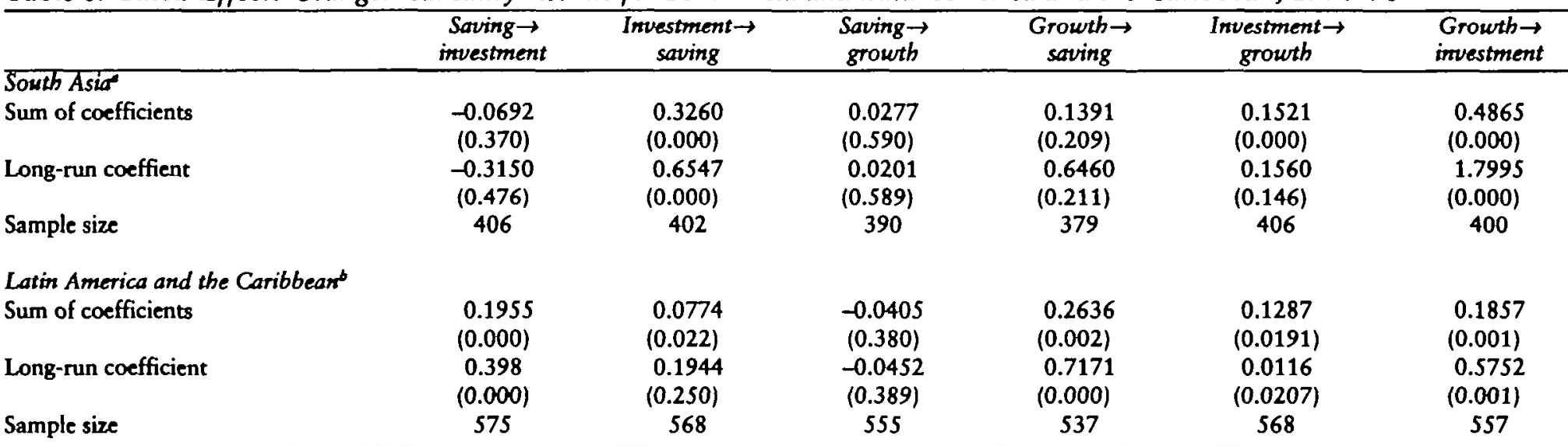

Note: Sum is the sum of the Granger-causality coefficients in the estimation equations. The long-run coefficient is derived by dividing this sum by 1 minus the sum of the coefficients of the lagged dependent variables. The numbers in parentheses are $p$-values.

a. South Asia includes Bangladesh, Bhutan, Cook Island, India, Maldives, Myanmar, Nepal, Pakistan, and Sri Lanka.

b. Latin America and the Caribbean includes Antigua and Barbuda, Argentina, the Bahamas, Barbados, Belize, Bolivia, Brazil, Chile, Colombia, Costa Rica, Dominica,

Dominican Republic, Ecuador, EJ Salvador, Grenada, Guatemala, Guyana, Haiti, Honduras, Jamaica, Mexico, Nicaragua, Panama, Paraguay, Peru, St. Kitts and Nevis,

St. Lucia, St. Vincent and the Grenadines, Suriname, Trinidad and Tobago, Uruguay, and Venezuela. Source: Authors' calculations based on data in the World Bank's World Saving Database. 
Our specification is broadly similar to other empirical models in the literature (such as Edwards 1995; Masson, Bayoumi, and Samiei 1995; and Mwega 1996). Private saving is assumed to depend on five types of variables, characterizing the life cycle, fiscal policy, the financial sector, macroeconomic stability, and openness of the economy. ${ }^{7}$ The estimation results are based on pooled ordinary least squares regressions, which include regional dummies for Sub-Saharan Africa and for Latin America and the Caribbean to determine whether the private saving rate in the two regions differs systematically from that in South and East Asia (table 7). ${ }^{8}$ The shift dummy variable for Africa is not significant at the 10 percent level, while that for Latin America is negative and significant at the 1 percent level. In this database, therefore, the saving rate in Africa is not significantly different from that in Asia after taking into account the various fundamentals.

Gross private disposable income (GPDI) per capita has a positive and generally significant coefficient $(0.033)$ among these developing countries. Growth of GPDI per capita also has a positive and highly significant coefficient, suggesting the existence of a virtuous cycle between private saving and growth. A 1 percent increase in economic growth raises the private saving rate by $0.053-0.081$ percentage point. Similarly, growth of the terms of trade has a positive and significant coefficient, with a 1 percent improvement in the terms of trade increasing the private saving rate by $0.11-0.12$ percentage point. An improvement in the terms of trade increases income and hence saving, especially if the improvement is expected to be transitory. This effect is particularly important in Sub-Saharan Africa, where exports are limited to a few primary commodities, which are sold in highly volatile markets. This result is corroborated by other empirical studies (such as Ostry and Reinhart 1992; Bevan, Collier, and Gunning 1992; and Azam 1996). Bevan, Collier, and Gunning (1992) analyze the impact of the 1976-77 coffee boom on rural saving in Kenya. Proceeds from this boom-caused by a frost in Brazil-were fully passed on to farmers, who saved about 60 percent of them.

Two demographic variables-the youth dependency ratio (the ratio of the population under 15 years to the population 15-64 years) and urbanization (the

7. A more detailed discussion of the channels through which these determinants affect private saving is contained in Mwega (1996).

8. An expanded version of this article (Elbadawi and Mwega 1999) contains regression results based on fixed-effects and GMM models. Controlling for fixed effects substantially changes the precision of several coefficients because some variables, such as demographics, change slowly over time and because of multicollinearity among variables. Income per capita, the youth dependency ratio, and urbanization, for example, no longer have significant coefficients. Among the financial variables, the coefficient on the ex post real, rate of interest is no longer significant, although the spread between the lending and the deposit interest rates and the degree of financial depth (M2Y) now have positive and significant coefficients. The ratio of private sector credit to gross private disposable income (GPDI) has a larger negative and significant coefficient (changing from -0.22 to -0.27 ). In addition, inflation is no longer significant. Differencing the variables in the GMM-IV estimation reduces the precision of the pooled point estimates even further. Only three variables remain significant: growth in the terms of trade (the coefficient of 0.06 is in the range estimated earlier), the public savings rate (with a larger offset coefficient of abour 1), and the ratio of private sector credit to GPDI (with a reduced coefficient of -0.17 ). 
Table 7. Private Saving in Developing Countries: Ordinary Least Squares Pooled Regressions with Regional Dummies, 1970-95

\begin{tabular}{|c|c|c|}
\hline \multirow{2}{*}{$\frac{\text { Variable }}{\text { Constant }}$} & (1) & (2) \\
\hline & $\begin{array}{l}-0.3345 \\
(-2.160)\end{array}$ & $\begin{array}{l}-0.3477 \\
(-3.204)\end{array}$ \\
\hline Gross private disposable income per capita & $\begin{array}{r}0.0327 \\
(5.378)\end{array}$ & $\begin{array}{r}0.0334 \\
(8.131)\end{array}$ \\
\hline $\begin{array}{l}\text { Growth of gross private disposable income } \\
\text { per capita }\end{array}$ & $\begin{array}{r}0.0531 \\
(1.715)\end{array}$ & $\begin{array}{r}0.0812 \\
(2.964)\end{array}$ \\
\hline Growth in the terms of trade & $\begin{array}{r}0.1129 \\
(3.713)\end{array}$ & $\begin{array}{c}0.1192 \\
(4.285)\end{array}$ \\
\hline Real investment rate & $\begin{array}{r}0.0447 \\
(3.241)\end{array}$ & $\begin{array}{r}0.0218 \\
(1.900)\end{array}$ \\
\hline Ratio of $\mathrm{M} 2$ to gross private disposable income & $\begin{array}{r}0.0318 \\
(0.583)\end{array}$ & \\
\hline Rate of public saving & $\begin{array}{r}-0.6048 \\
(11.202)\end{array}$ & $\begin{array}{r}-0.6374 \\
(13.324)\end{array}$ \\
\hline Youth dependency ratio & $\begin{array}{l}-0.3000 \\
(-5.390)\end{array}$ & $\begin{array}{r}0.2840 \\
(-6.041)\end{array}$ \\
\hline Elder dependency ratio & $\begin{array}{r}0.7430 \\
(0.059)\end{array}$ & \\
\hline Urbanization index & $\begin{array}{r}-0.0810 \\
(-2.820)\end{array}$ & $\begin{array}{r}-0.0778 \\
(-3.398)\end{array}$ \\
\hline Government consumption & $\begin{array}{r}0.6824 \\
(7.801)\end{array}$ & $\begin{array}{r}0.7659 \\
(10.985)\end{array}$ \\
\hline $\begin{array}{l}\text { Spread between lending and borrowing } \\
\text { interest rates }\end{array}$ & $\begin{array}{r}0.0008 \\
(1.265)\end{array}$ & \\
\hline $\begin{array}{l}\text { Ratio of domestic credit to the private sector } \\
\text { to gross private disposable income }\end{array}$ & $\begin{array}{l}-0.1635 \\
(-4.122)\end{array}$ & $\begin{array}{l}-0.1586 \\
(-5.060)\end{array}$ \\
\hline Inflation rate & $\begin{array}{l}-0.0794 \\
(-4.092)\end{array}$ & $\begin{array}{r}-0.0790 \\
(-4.793)\end{array}$ \\
\hline Ratio of foreign aid to gross domestic product & $\begin{array}{l}-1.0906 \\
(-4.246)\end{array}$ & $\begin{array}{l}-0.8968 \\
(-4.429)\end{array}$ \\
\hline Sub-Saharan Africa dummy & $\begin{array}{r}0.0461 \\
(1.478)\end{array}$ & \\
\hline Latin America and the Caribbean dummy & $\begin{array}{r}-0.0737 \\
(-3.333)\end{array}$ & $\begin{array}{c}-0.0846 \\
(-5.879)\end{array}$ \\
\hline Sample size & 260 & 306 \\
\hline Adjusted $R^{2}$ & 0.55 & 0.597 \\
\hline Standard error & 0.092 & 0.090 \\
\hline
\end{tabular}

Note: The numbers in parentheses are $p$-values.

Source: Authors' calculations based on data in the World Bank's World Saving Database.

proportion of the urban population in the total population)-have negative and significant coefficients. The life-cycle model predicts a negative relationship between the private saving rate and the dependency ratio, provided that the lifecycle motive for saving to finance retirement is important. Urbanization also may reduce the saving rate, as precautionary saving associated with the volatility of income in the agricultural sector is reduced. This effect seems to dominate the 
increase in saving arising because urban dwellers may have better access to financial instruments.

Of the fiscal policy variables, public saving has a negative and significant effect. An increase in the rate of public saving by 1 percent reduces the private saving rate by about 0.6 percentage point. General government consumption has a positive and significant coefficient of $0.68-0.77$. For a given rate of public saving, policies that reduce government consumption expenditures (and reduce tax revenues) have a negative impact on the private saving rate. This result suggests that the private sector places positive value on government consumption (Edwards 1995).

Turning to the financial variables, the pooled results show that the coefficient on the ex post real rate of interest, which captures financial liberalization (or the absence of financial repression), is positive and significant (0.02-0.04), although the spread between the lending and the deposit interest rates is not significant. Similarly, the degree of financial depth (M2Y) has an insignificant coefficient. The degree to which financial constraints are binding was proxied by domestic credit allocated to the private sector relative to GPDI. The coefficient of this variable is negative and significant $(-0.16)$, suggesting that liquidity and borrowing constraints are important among these developing countries.

In the category of macroeconomic instability and volatility, the pooled results show. that inflation has a negative and significant coefficient. Inflationary expectations lead to a lower real rate of interest and adversely affect private saving through the McKinnon-Shaw mechanism (McKinnon 1973, 1991; Shaw 1973). High inflation also may signal a lack of credibility in government policies, as well as lower expected returns on saving. The estimation suggests that these two effects of inflation more than outweigh its potential effect through the reduction of real wealth (if, because of structural rigidities, it is not fully indexed) and consumption, which would lead to an increase in saving.

Ending with the open economy variable, the results suggest that the degree of dependence on foreign aid, as measured by the ratio of foreign aid to GPDI, has a negative and significant coefficient, with an almost one-for-one offset relationship (that is, a 1 percent rise in foreign aid will lead to a I percent decline in private saving). Although foreign aid traditionally has been regarded as complementary to national saving, a resurgent literature on the macroeconomic effects of foreign aid finds that additional aid is spent mostly on consumption, not investment (Boone 1994 and Obstfeld 1995)..$^{9}$ This means that foreign saving will, on average, act as a substitute for domestic saving by easing liquidity constraints

9. Complementarity can be derived from certain poverty trap models (in which inflows of foreign savings help to unlock these traps) or models in which countries converge to common steady-state income levels (Boone 1994). If incomes converge, then poor countries will save a part of the transfers, since these are temporary. Developing countries also may have a higher marginal productivity of capital, which induces thern to postpone consumption to the future. Foreign aid may be used to construct infrastructure, leading to a reduction in distortionary taxes and hence promoting economic growth. This assumes that aid is given in a "good" policy environment, in which aid is found to be conducive to growth only in such an environment (Burnside and Dollar 1996). But if incomes across countries do not converge, the flow of foreign aid is likely to be perceived as permanent and therefore largely spent on consumption. 
or by inducing Dutch-disease effects. As Africa is the world's main recipient of aid (relative to the size of its economy), the impact of aid on private saving is of utmost importance to both the donor community and African policymakers.

\section{Saving Performance within Sub-Saharan Africa}

Despite the weak saving performance of Sub-Saharan Africa relative to other regions, it is important to emphasize that Sub-Saharan Africa is not an undifferentiated whole. For example, during 1970-95 the median saving rate (as a proportion of disposable income) of the high-saving Sub-Saharan African countries was more than 9.8 percent greater than the rate of moderate-saving countries, which in turn was more than 4.7 percent greater than that of the low-saving countries. However, even the average saving rate of the high savers (17.9 percent) was much lower than the average rate of the high-performing Asian economies (more than 24.8 percent). Understanding the sources of Asia's superior performance as well as the diversity within Sub-Saharan Africa should be an important policy objective.

We conduct historical simulations to decompose the differences in saving rates between the high-performing Asian economies and the Sub-Saharan African high and moderate savers (using regression 2 of table 7; see table 8). We carry out the decomposition by computing the contribution to the saving rate of each variable found to be significantly associated with private saving. These shares are derived by multiplying the variable's mean (for each of the four groups) by its estimated coefficient. The differences between the shares of the high-performing Asian economies and the shares of African countries are the sources of the overall difference in saving between the two regions. We also conduct a similar decomposition of the difference between moderate and low savers in Sub-Saharan Africa. These experiments give us some insight into what low-saving Sub-Saharan African countries might do to raise their private saving rates to the level of the moderate savers and what moderate- and high-saving African countries might do to approach the East Asian frontier.

Comparing the high-performing Asian economies with the high and moderate African savers, we can make the following points. First, GPDI per capita and the youth dependency ratio emerge as the most important, robust contributors to East Asia's superior saving performance. For example, in 1970-95 the differential GPDI per capita and the youth dependency ratio equaled 18.0 and 6.2 percent in favor of high-performing Asian economies relative to high savers (and 14.4 and 9.2 percent relative to moderate savers). Second, the high aid dependence of moderate savers, and to a lesser degree of high savers, also contributed to East Asia's saving advantage. We estimate that because of this dependence, moderate savers lagged behind the high-performing Asian economies by 3.7 percent in 197095. For high savers this shortfall was much lower, at 1.7 percent.

Third, as expected, the first-round effect of East Asia's higher public saving relative to that of Sub-Saharan Africa lessened the saving differential between the 
Table 8. Savings Performance in Sub-Saharan Africa and the High-Performing Asian Economies, 1970-9S (percentage contribution to differential in savings rates)

\begin{tabular}{|c|c|c|c|c|}
\hline \multirow[b]{2}{*}{ Variable } & \multirow[b]{2}{*}{ Coefficient } & \multicolumn{2}{|c|}{ High-performing Asian economies to } & \multirow[b]{2}{*}{$\begin{array}{c}\text { Moderate-saving Sub- } \\
\text { Sabaran African countries } \\
\text { to low-saving Sub-Sabaran } \\
\text { African countries }\end{array}$} \\
\hline & & $\begin{array}{l}\text { High-saving } \\
\text { Sub-Saharan } \\
\text { African } \\
\text { countries } \\
\end{array}$ & $\begin{array}{l}\text { Moderate-saving } \\
\text { Sub-Saharan } \\
\text { African } \\
\text { conntries } \\
\end{array}$ & \\
\hline $\begin{array}{l}\text { Gross private disposable income per } \\
\text { capita }\end{array}$ & 0.0334 & 18.04 & 14.44 & 4.16 \\
\hline $\begin{array}{l}\text { Growth of gross private disposable } \\
\text { income per capita } \\
\text { Youth dependency ratio } \\
\text { Urbanization index }\end{array}$ & $\begin{array}{r}0.0812 \\
-0.2840 \\
-0.0778\end{array}$ & $\begin{array}{l}0.59 \\
6.24 \\
1.55\end{array}$ & $\begin{array}{r}0.44 \\
9.20 \\
-2.20\end{array}$ & $\begin{array}{l}-0.11 \\
-1.06 \\
-0.29\end{array}$ \\
\hline $\begin{array}{l}\text { Fiscal policy variables } \\
\text { Rate of public saving } \\
\text { Government consumprion }\end{array}$ & $\begin{array}{r}-0.6374 \\
0.7659\end{array}$ & $\begin{array}{l}-2.54 \\
-5.85\end{array}$ & $\begin{array}{l}-2.31 \\
-3.82\end{array}$ & $\begin{array}{l}0.24 \\
0.50\end{array}$ \\
\hline $\begin{array}{l}\text { Financial variables } \\
\text { Real interest rate } \\
\text { Ratio of domestic credit to the private } \\
\text { sector to gross private disposable } \\
\text { income per capita }\end{array}$ & 0.0218 & -5.67 & -5.34 & -0.05 \\
\hline $\begin{array}{l}\text { Macroeconomic and external variables } \\
\text { Inflation rate } \\
\text { Growth in the terms of trade }\end{array}$ & $\begin{array}{r}-0.0790 \\
0.1192\end{array}$ & $\begin{array}{l}0.34 \\
1.05\end{array}$ & $\begin{array}{l}0.57 \\
1.06\end{array}$ & $\begin{array}{l}0.68 \\
0.12\end{array}$ \\
\hline $\begin{array}{l}\text { Foreign aid } \\
\text { Ratio of foreign aid to gross domestic } \\
\text { product }\end{array}$ & -0.8968 & 1.74 & 3.68 & 2.05 \\
\hline $\begin{array}{l}\text { Explained difference } \\
\text { Actual difference } \\
\text { Unexplained residual }\end{array}$ & & $\begin{array}{r}12.44 \\
7.87 \\
-4.57\end{array}$ & $\begin{array}{r}15.93 \\
16.34 \\
0.42\end{array}$ & $\begin{array}{r}4.44 \\
2.23 \\
-2.21\end{array}$ \\
\hline
\end{tabular}

Note: The high-performing Asian economies include China, Hong Kong, Indonesia, the Republic of Korea, Malaysia, Singapore, Taiwan (China), and Thailand. The high-Saving Sub-Saharan African countries include Gabon, Seychelles, Liberia, South Africa, Namibia, Mauritius, Lesotho, Kenya, Tanzania, Congo, Togo, and Zimbabwe. The moderate-saving Sub-Saharan African countries include Benin, Burkina Faso, Cameroon, Comoros, Congo, Cóte d'lvoire, Ethiopia, Guinea, Malawi, Mali, Mauritania, Niger, Nigeria, Rwanda, Senegal, Sudan, Swaziland, Zambia, and Zimbabwe. The low-\$aving Sub-Saharan African countries include Botswana, Burundi, Central African Republic, Chad, Gambia, Ghana, Guinea Bissau, Madagascar, Såo Tomé and Principe, Sierra Leone, and Uganda.

a. The coefficients are from regression 2 of table 7 .

Source: Authors' calculations based on data in the World Bank's World Saving Database. 
two. ${ }^{10}$ However, this effect was relatively small (reaching a maximum of -2.5 percent for the high savers) compared with the huge, positive effect of income per capita and the life-cycle variables in favor of saving in the high-performing Asian economies. Higher government consumption in Sub-Saharan Africa lessened the saving differential between Africa and East Asia, compounding the effects of higher public saving in the high-performing Asian economies.

Fourth, and perhaps not surprising, the contributions of the financial and macroeconomic variables were small. ${ }^{11}$ However, the share of private sector credit in GPDI had a large impact (5.7 and 5.4 percent in high and moderate savers, respectively) in favor of Sub-Saharan Africa, whereas the growth of the terms of trade favored private saving in high-performing Asian economies by about 1 percentage point. ${ }^{12}$

The factors differentiating moderate- and low-saving African countries are broadly similar to those above, with a few differences. Again, the effect of income per capita was very important, contributing 4.2 percent to the better saving performance of the moderate savers. This finding underscores the importance of raising income per capita within Sub-Saharan Africa.

Unlike the comparisons between Sub-Saharan Africa and the high-performing Asian economies, the higher dependency ratio among the moderate savers reduces the differential with low savers. Thus these life-cycle variables make a net positive contribution to saving in low savers relative to moderate savers. The net effect of the other life-cycle variables is, however, negligible. This leaves aid dependence as the only variable making a relatively appreciable contribution (2.0 percent) to the higher private saving rate in moderate savers. The marginal role of macroeconomic and financial variables in explaining the divergent saving performance of the high-performing Asian economies and Sub-Saharan Africa is also corroborated in the comparison between moderate and low savers.

Despite the insights into the main reasons that saving diverges across countries, some major gaps remain in the analysis. For example, in comparing the high-performing Asian economies with Sub-Saharan Africa, the cross-country model tends to underestimate saving rates in high- and low-saving African countries, as reflected by fairly large negative unexplained residuals. However, the model tends to slightly overstate saving rates in moderate-saving countries. We may gain further insight into the saving process in Sub-Saharan Africa by analyzing country-specific experiences.

10. This analysis is based on partial equilibrium simulations and therefore does not capture the secondround (and positive) effects of public saving on private saving, given public saving's positive influence on growth. Thus this analysis may also overnate the growth effect on private saving.

11. Because macroeconomic variables are part of the economic growth fundamentals, this analysis does not account for their potentially powerful (and positive) second-round effects on private saving.

12. This is despite disregarding the large mean value (6.68) of Hong Kong's ratio of domestic credit to the private sector to GPD. 


\section{COUNTRY EXPERIENCES IN SUb-SaHaran Africa}

We analyze three Sub-Saharan African countries, two of which-Kenya and Zimbabwe-are high savers, whereas the third, Botswana, has one of the lowest private saving rates in Sub-Saharan Africa (see table 9). However, Botswana's unusually high public saving rate makes it one of the top savers (in terms of aggregate national saving) in the world. These countries present interesting anomalies, which should help to highlight the role of some variables that may not be easily captured by the regression model.

\section{Kenya and Zimbabwe}

The most important reasons for the high private saving rates in Kenya and Zimbabwe are that both countries have relatively dense and diversified financial and banking sectors and have instituted the policy of institutional "forced" sav-

Table 9. Savings Performance in Kenya, Zimbabwe, and Botswana Relative to the High-Performing Asian Economies, 1970-95

(percentage contribution to differential in saving rates)

\begin{tabular}{|c|c|c|c|c|}
\hline Variable & Coefficient & Kenyat & Zimbabwe & Botswana \\
\hline $\begin{array}{l}\text { Gross private disposable } \\
\text { income per capita } \\
\text { Growth of gross private } \\
\text { disposable income per capita } \\
\text { Youth dependency ratio } \\
\text { Urbanization index }\end{array}$ & $\begin{array}{r}0.0812 \\
-0.2840 \\
-0.0778\end{array}$ & $\begin{array}{r}0.63 \\
14.85 \\
-2.63\end{array}$ & $\begin{array}{r}0.84 \\
11.85 \\
-2.18\end{array}$ & $\begin{array}{r}-0.01 \\
13.42 \\
-2.64\end{array}$ \\
\hline $\begin{array}{l}\text { Fiscal policy variables } \\
\text { Rate of public spending } \\
\text { Government consumption }\end{array}$ & $\begin{array}{r}-0.6374 \\
0.7659\end{array}$ & $\begin{array}{l}-3.65 \\
-5.83\end{array}$ & $\begin{array}{l}-3.79 \\
-9.09\end{array}$ & $\begin{array}{r}19.47 \\
-26.15\end{array}$ \\
\hline $\begin{array}{l}\text { Financial variables } \\
\text { Real interest rate } \\
\text { Ratio of domestic credit to the } \\
\text { private sector to gross private } \\
\text { disposable income }\end{array}$ & -0.1586 & -5.15 & -6.94 & -4.59 \\
\hline $\begin{array}{l}\text { Mactoeconomic and external var } \\
\text { Inflation rate } \\
\text { Growth in the terms of trade }\end{array}$ & $\begin{array}{r}\text { les } \\
-0.0790 \\
0.1192\end{array}$ & $\begin{array}{l}0.53 \\
0.74\end{array}$ & $\begin{array}{l}0.50 \\
1.15\end{array}$ & $\begin{array}{l}0.36 \\
0.03\end{array}$ \\
\hline $\begin{array}{l}\text { Foreign aid } \\
\text { Ratio of foreign aid to gross } \\
\text { domestic product }\end{array}$ & -0.8968 & 1.64 & 0.89 & 2.94 \\
\hline $\begin{array}{l}\text { Explained difference } \\
\text { Actual difference } \\
\text { Unexplained residual }\end{array}$ & & $\begin{array}{r}13.06 \\
-1.01 \\
-14.07\end{array}$ & $\begin{array}{r}-3.13 \\
3.71 \\
6.85\end{array}$ & $\begin{array}{r}21.23 \\
11.26 \\
-9.98\end{array}$ \\
\hline
\end{tabular}

Note: The high-performing Asian economies include China, Hong Kong, Indonesia, the Republic of Korea, Malaysia, Singapore, Taiwan (China), and Thailand. South Asia includes Bangladesh, Bhutan, Cook Island, India, Maldives, Myanmar, Nepal, Pakistan, and Sri Lanka.

a. Kenya savings data are unadjusted for capital gains and losses from inflation.

Source: Authors' calculations based on data in the World Bank's World Saving Database. 
ing. The policy of forced saving is based on an elaborate ensemble of regulations for the appropriation of private saving to finance fiscal expenditures. ${ }^{13}$ Until recently, especially in Zimbabwe, the policy also was reinforced by an extensive and effective system of foreign exchange and import controls. The mechanism for mobilizing forced saving in Zimbabwe is succinctly described in Elbadawi and Schmidt-Hebbel (1991: 7-8):

To generate a surplus which finances 100 percent or more of the public deficit since $1986 / 87$, the private sector raised significantly its saving rate: since 1984/85 it exceeds 20 percent of GDP and finances more than 100 percent of the economy's gross domestic investment. This private saving rate is very high for a developing economy-a counterpart is a very low private consumption rate, barely exceeding 50 percent of GDP during the second half of the 1980s. High private saving channeled through Zimbabwe's developed financial system to the public sector is probably a result of restrictions on private consumption (particularly imported consumer durables) and on formal or illegal capital outflows.

Perhaps to a lesser extent than Zimbabwe, Kenya also accorded a fair degree of protection to domestic industry until the early 1990 s.

The history of Zimbabwe's banking and financial system dates back to the 1 890 s. The system is composed of nine institutions, including commercial banks, accepting houses, discount houses, finance houses, post office saving funds, building societies, insurance companies, pension and provident funds, and saving clubs. The robustness and diversity of the Zimbabwean financial sector has enabled it to mobilize small saving from a large number of clients from rural communities and small towns, through small institutions, such as post office saving funds, which realized their largest expansion during the first half of the 1980s. The assets of these funds (as a proportion of total assets of the financial sector) rose from 13 percent in 1983 to more than 20 percent in 1986-almost half the assets of commercial banks, which are the most important institutions for mobilizing private saving in Zimbabwe. Commercial banks and other more formal financial institutions also have managed to mobilize large saving from the corporate and commercial sectors (Moyo 1996).

The financial sector in Kenya also is considered to be one of the deepest and most diversified in Sub-Saharan Africa. A measure of its success in mobilizing private saving is reflected in its contribution to gross domestic saving, which averaged about 40 percent during the second half of the 1980 s. Private nonfinancial corporations also are important contributors, accounting for an additional 36 percent of gross domestic saving during the same period (Kwasa 1992).

Despite the superior saving performance of Kenya and Zimbabwe relative to that of most other African countries, two important questions arise: what might

13. For example, insurance companies in Zimbabwe are required to invest at least 60 percent of their funds in prescribed government securities (Moyo 1996). 
these countries do to raise their private saving rates to the levels of the highperforming Asian economies, and what is the likely effect of trade and financial liberalization-introduced in both countries since the late $1980 \mathrm{~s}-$ on private saving? The answer to the first question seems fairly straightforward and is readily obtained from the pooled saving model. The two countries must increase income per capita, for which both macroeconomic stability and competitiveness may be critical. Moreover, the two countries need to reduce their age-dependency ratios.

Financial liberalization appears to have no significant positive impact on saving, which is consistent with the cross-country evidence of this article and country-specific evidence for a range of African countries. Whereas Kenya's saving rate remained stable between the second half of the 1980s and the first half of the 1990s, Zimbabwe's saving rate fell in the 1990s (Ndung'u 1997). Why financial liberalization may not have yet led to a surge in private saving in these two countries may have to do with their-especially Zimbabwe's-failure to further financial deepening or to increase the efficiency of the financial sector. Although in Kenya the ratio of M2 to GDP increased from 38 percent in 1980 to around 50 percent in 1994, it declined slightly from more than 50 to 48 percent in Zimbabwe. More compelling evidence, however, is the perverse rise in the spread between the lending and the deposit rate (an indicator of inefficiency in the financial market) during financial liberalization. In Kenya it increased from more than 5 percent in 1989 to more than 18 percent in 1994, and in Zimbabwe it increased from 1.4 percent to more than 8 percent in 1994 (Ndung'u 1997).

In the final analysis it seems that the ability of the two countries to maintain relatively high levels of private saving may reflect that both the policy of forced saving (arising because trade liberalization has been only partial so far) and dense and relatively robust financial markets are still operating. Therefore, adjustment to a higher voluntary saving rate-and more efficient investment and therefore higher growth-has yet to begin in the two countries.

\section{Botswana}

Botswana may be one of the few countries that have been able to achieve high and sustained growth despite persistently low private saving rates. Clearly, given its growth record, Botswana's unusually high public saving rate has more than compensated for its low private saving rate. On average, the private saving rate in Botswana during 1970-95 lagged behind the median rate in Sub-Saharan Africa by about 3.5 percent. ${ }^{14}$ In contrast to its record of private saving, Botswana managed to achieve an impressive record of growth, including an average annual per capita growth rate of more than 11 percent during 1969-79 and almost 7 percent during 1980-90. By any standard, Botswana has indeed earned its position as one of the leading developing countries to make a sustainable transition

14. However, Botswana has closed the gap over time. In 1990-95 its savings rate exceeded the median for Sub-Saharan Africa by 3.6 percent. 
to high growth and low macroeconomic instability (Elbadawi and Schmidt-Hebbel 1997).

Public saving constitutes more than 75 percent of Botswana's staggering gross domestic saving rates, which averaged about 42 percent in 1985-89 and more than 33 percent in the first half of 1990s. Government revenue in Botswana was given a tremendous boost by an increase in the production and export of diamonds. The government collects "between 75 and 82 percent of the profit of the diamond industry through a combination of royalty payments, profit tax, withholding tax on remitted dividends, and dividends received by virtue of its 50 percent share-holding in the diamond mining company Debswana" (Hope 1997: 107). However, the experiences of other well-endowed resource-based economies suggest that Botswana's unusual record of public saving owes more to prudent fiscal management than to the sheer magnitude of its wealth.

Naturally, the key test of Botswana's macroeconomic prudence was the challenge of managing the boom in the mining sector (diamonds). In the words of Norberg and Blomstrom (1993: 176-77),

The spending effects of the diamond boom have been small, something which is mainly due to government policy. Since the diamond industry is state owned, the government controls the revenues. The revenues have mainly been used to promote national income, rather than to subsidize different sectors (such as import-substituting manufacturing) and support various interest groups. To maximize national income, a large proportion of the revenues from diamonds have been invested, not in Botswana, but in foreign banks and firms. By sterilizing revenues abroad and executing a nonexpansive monetary policy at home, the inflationary pressure has diminished and the negative effects of the diamond boom have been reduced.

Despite its enormous success in growth and the management of its nonrenewable resource-based economy, Botswana must substantially raise its private saving rate without necessarily reducing its current public saving. There are three arguments in support of this view. First, since the mainstay of the economy is a nonrenewable resource, intertemporal welfare maximization suggests that optimal saving rates-consistent with maintaining current consumption rates-could be as high as 50 percent of GDP (Elbadawi and Majd 1992). An optimal saving rate (relative to GDP) has been computed at about 37 percent of GDP for countries, such as Egypt, Turkey, and Indonesia, that only partially depend on a nonrenewable resource, such as oil. For countries that are more heavily dependent on oil, such as Saudi Arabia and the United Arab Emirates, the optimal saving rate could be as high as 60 percent. Botswana clearly belongs to the latter group. ${ }^{15}$ There-

15. The framework used to derive the optimal rate is a model of a small open economy with two assets (such as oil and an asset other than oil). We can solve for the optimal savings rate in this model as an explicit function of the life span of the reserve of the nonrenewable resource, expected future prices of the resource, the real returns of investment, and the desirable savings rate in the post-resource era. Examples of this literature include Dervis, Martin, and van Wijnbergen (1984); Gelb (1985a, 1985b); Farin (1990); and Askari (1990). 
fore, a higher private saving rate would be required to help bridge the gap between the prevailing national saving rate and the welfare-maximizing rate for an economy such as Botswana's.

Second, despite Botswana's enormous success in sustaining high growth and prudently managing its mineral sector, a new body of evidence suggests that this growth has not been equitable and has coexisted with poverty and unemployment (Hope and Edge 1996). Thus an increasing share of public saving should be spent on the social sectors, with the implication that, to sustain growth, more private saving will be needed to support other vital investments. Further, given the volatility of the mining sector, a high and stable rate of private investment should always be a major policy objective.

Even though the partial crowding out effect of the high rate of public saving in Botswana unavoidably reduces private saving, other policy-induced factors also have contributed to this outcome. ${ }^{16}$ One factor is financial repression-even after rising significantly, real interest rates in Botswana were still negative during the 1990s at -0.3 percent (Ndung'u 1997). More important, however, is the lack of deep and diversified financial and banking sectors.

The need for raising private saving is now well understood in Botswana. For example, the private sector is calling for a major drive toward privatizing parastatals-through share offerings-as the most effective method for mobilizing private saving (Hope 1997).

\section{CONCLUSIONS}

Sub-Saharan Africa's growth performance over the past two decades has been poor relative to that of other regions, especially the high-performing Asian economies. This poor performance also has been reflected in low saving and investment rates, both of which declined substantially in the 1970s and the 1980s, recovering only partially in the 1990 s. A worrisome feature of saving and investment in Sub-Saharan Africa is the region's heavy dependence on foreign saving, mostly overseas development assistance, to finance the gap between investment and saving. This article focused on the determinants of private saving in SubSaharan Africa, with the objective of explaining the region's dismal saving behavior and ultimately identifying policies that could reverse the decline in saving. Although raising saving rates alone is not sufficient for achieving sustained growth, it does appear to be a necessary condition.

Results of a fixed-effects estimation suggest that in Sub-Saharan Africa causality runs from growth to investment (and perhaps to private saving), which is consistent with international evidence (see, for example, Carroll and Weil 1993). A rise in the saving rate also seems to Granger-cause an increase in investment. However, foreign aid Granger-causes a reduction in both saving and investment.

16. According to model simulations (not reported) this effect causes private saving in Botswana to be 12 percent less than the median savings rates in Sub-Saharan Africa for the 1990-95 period. 
Investment also Granger-causes an increase in foreign aid, so that African countries that increase investment receive more aid.

We can make several broad conclusions from the empirical analysis of private saving in Sub-Saharan Africa and other regions over 1970-95. First, including regional dummies for Sub-Saharan Africa and Latin America and the Caribbean in the regressions to test whether the two regions differ systematically from Asia reveals that the Africa shift dummy is not significant at the 10 percent level, while that of Latin America is negative and significant at the 1 percent level. Second, GPDI per capita, the growth of GPDI per capita, and the growth in the terms of trade have positive and significant coefficients. The youth dependency ratio and urbanization ratio have negative and significant coefficients.

Third, the public saving coefficient is negative and highly significant, with an offset coefficient of about -0.6 percent ( $a$ rise in public saving by 10 percent will reduce private saving by 6 percent). General government consumption, in contrast, has a positive and significant coefficient, indicating that the private sector places positive value on government consumption (Edwards 1995). The coefficient on the ex post real rate of interest is positive and significant, while the coefficient on the private sector credit ratio is negative and significant. Both inflation and foreign aid have negative and significant coefficients.

We used the regression results to analyze the main factors that drive saving for three subgroupings from Sub-Saharan Africa (high, moderate, and low savers) and three countries (Kenya, Zimbabwe, and Botswana). The analysis is based on historical simulations of the sources of the differences in saving rates between high-performing Asian economies and each of the Sub-Saharan African groups. Income per capita and the youth dependency ratio emerge as the most important contributors to the superior saving performance in high-performing Asian economies relative to that in high and moderate African savers. The high dependence on aid among moderate savers and to a lesser degree among high savers also has given the high-performing Asian economies an advantage in terms of saving performance. However, Asia's higher public saving rate relative to that of the two Sub-Saharan African groups reduced the saving differential, although this effect is relatively small compared to the huge effect of the life-cycle variables, which work in the opposite direction. Moreover, higher government consumption in Sub-Saharan Africa (especially among high-saving African countries) lowers the differential, compounding the effect of higher public saving in the highperforming Asian economies. The contributions of financial and macroeconomic variables are small, except for the private sector credit ratio, which favors SubSaharan Africa.

In comparing moderate savers to low savers in Sub-Saharan Africa, the patterns are broadly similar. But there are some differences. First, the effect of income per capita is very important, but the higher dependency ratio among the moderate savers reduces the differential with the low savers. Thus life-cycle variables make a net positive contribution to saving in low-saving countries relative to moderate-saving countries. Second, dependence on aid contributes appreciably to the higher private saving rate among moderate savers relative to low sav- 
ers. Third, the marginal role of macroeconomic and financial variables in explaining the divergent saving performance of high-performing Asian economies and Sub-Saharan Africa also is corroborated in the comparison between moderate and low savers.

Finally, this article provided further insight into the saving process in SubSaharan Africa by analyzing the experiences of Kenya, Zimbabwe, and Botswana.

\section{Data Appendix: Variable Defintmons and Data Sources}

Most of the data used in sections II and III were derived from the World Bank's World Saving Database.

- GPDI is measured by gross national disposable income minus gross public disposable income. The latter was estimated by public saving plus public consumption.

- GPRS is a residual measure of private saving (gross national saving minus central government saving) in the database adjusted for capital gains or losses due to inflation. This adjustment did not change the results substantially. The measure of private saving was scaled by gross private disposable income. The other measures of saving in the World Bank's data that net out saving by other public sector entities and, therefore, provide a better separation between private and public saving, had too many missing observations, particularly in the Sub-Saharan Africa sample, to permit meaningful analysis.

- $L R P Y C$ is the log of real per capita gross private disposable income.

- $\triangle L R Y P C$ is the change in $L R Y P C$ (that is, growth in real per capita GPDI).

- $\triangle L T O T$ is the change in log terms of trade.

- RDRATE is the real deposit rate of interest, expressed as $\log (1+\rho)$ to reduce the range of variation.

- $M 2 Y$ is $\mathrm{M} 2$ as a proportion of GPDI.

- GPS is central government saving as a proportion of GPDI. These saving, as in GPRS, are controlled for capital gains or losses due to inflation.

- D15 is the youth dependency ratio, measured by the ratio of the population under 15 years to the population 15-64 years.

- D65 is the elder dependency ratio, measured by the ratio of the population over 64 years to the population $15-64$ years.

- URBAN is the degree of urbanization, measured by the proportion of urban population to the total population.

- GCNY is general government consumption expenditures as a proportion of GPDI.

- RSPREAD is the spread between lending and borrowing interest rates given in the database.

- $D C P C Y$ is the proportion of the stock of private sector domestic credit to GPDI.

- INFL is inflation, expressed by $\log (1+\pi)$ to reduce the range of variation. 
- AIDY is dollar foreign aid as a proportion of dollar GPDI. The data for the dollar foreign aid were derived from a compilation by Chang and others (1998). They define effective development assistance as the sum of grantequivalents and grants, excluding technical assistance. To derive the dollar GPDI, the exchange rate given in the World Saving Database was used.

\section{REFERENCES}

The word "processed" describes informally reproduced works that may not be commonly available through library systems.

Allerano, Manuel, and Stephen Bond. 1991. "Some Tests of Specification for Panel Data: Monte Carlo Evidence and an Application to Employment Equation." Review of Economic Studies 58(2):277-98.

Askari, Hossein. 1990. Saudi Arabia's Economy: Oil and the Search for Economic Development. Contemporary Studies in Economic and Financial Analysis 67. Greenwich, Conn.: JaI Press.

Attanasio, O. P., Lucio Picci, and Antonello Scorcu. 2000. "Saving Growth and Investment. Review of Economics and Statistics 82(2): 182-211.

Azam, Jean-Paul. 1996. "Saving and Interest Rates: The Case of Kenya." Savings and Development. 20(1): 33-44.

Bevan, David, Paul Collier, and Jan W. Gunning. 1992. “Anatomy of a Temporary Trade Shock: The Kenya Coffee Boom of 1976-79." Journal of African Economies 1(2): 271-305.

Boone, Peter. 1994. "The Impact of Foreign Aid on Savings and Growth." London School of Economics, Centre for Economic Performance, London. Processed.

Bosworth, Barry. 1993. Saving and Investment in an Open Economy. Washington D.C.: Brookings Institution.

Burnside, Craig, and David Dollar. 1996. Aid, Policies, and Growth. Washington, D.C.: World Bank.

Carroll, Chris, Jody Overland, and David Weil. 1994. "Savings and Growth with Habit Formation." Division of Monetary Affairs, Federal Reserve Board, Washington, D.C. Processed.

Carroll, Chris, and David Weil. 1993. "Savings and Growth: A Reinterpretation." NBER Working Paper 4470. National Bureau of Economic Research, Cambridge, Mass. Processed.

Chang, Charles C., Eduardo Fernandez-Arias, and Luis Servén. 1998. "Measuring Aid Flows." World Bank, Development Economics Division, Washington, D.C. Processed.

Cole, H. L., G. J. Mailath, and Andrew Postlewaite. 1992. “Social Norms, Savings Behavior, and Growth." Journal of Political Economy 100(6): 1092-125.

Collier, Paul. 1995. "The Marginalization of Africa." International Labour Review 134(45): 134(4-5): 541-57.

- 1998. "The Role of the State in Economic Development: Cross-Regional Experiences." Joumal of African Economies 7(2): 38-76.

De Long, J. Bradford, and Lawrence Summers. 1993. “How Strongly Do Developing Economies Benefit from Equipment Investment?" Joumal of Monetary Economics 32(3): $395-416$. 
Dervis, Kemal, Richard Martin, and Sweder van Wijnbergen. 1984. Policy Analysis of Shadow Pricing, Foreign Borrowing, and Resource Extraction in Egypt. World Bank Staff Working Paper 622. Washington, D.C.: World Bank.

Easterly, William, and Ross Levine. 1997. “Africa's Growth Tragedy: Policies and Ethnic Division." Quarterly Journal of Economics 112(4): 1203-50.

Easterly, William, and Sergio Rebelo. 1993. "Fiscal Policy and Economic Growth: An Empirical Investigation." Joumal of Monetary Economics 32(3):417-58.

Edwards, Sebastian. 1995. “Why Are Latin America's Saving Rates So Low? An International Comparative Analysis." Department of Economics, University of California, Los Angeles. Processed:

Elbadawi, Ibrahim, and Nader Majd. 1992. "Managing a Nonrenewable Resource: Savings and Exchange Rate Policies in Bahrain." Policy Research Working Paper 1134. World Bank, Transition and Macro-adustment Division and International Trade Division, Washington, D.C. Processed.

Elbadawi, Ibrahim, and Francis Mwega. 1999. “Can Africa's Saving Collapse Be Reverted?" World Bank, Development Research Group, Washington, D.C. Processed.

Elbadawi, Ibrahim, and Benno Ndulu. 1996. “Long-Term Development and Sustainable Growth in Sub-Saharan Africa." In Mats Lundahl and Benno Ndulu, eds., New Directions in Development Economics: Growth, Environmental Concerns, and Governance in the 1990s. London: Routledge.

Elbadawi, Ibrahim, Benno Ndulu, and Njuguna Ndung'u. 1997. "Economic Policy, Risk, and Uncertainty as Determinants of Investments in Sub-Saharan Africa." Paper presented at the tenth anniversary of the Centre for the Studies of the African Economies, University of Oxford, March. Processed.

Elbadawi, Ibrahim, and Klaus Schmidt-Hebbel. 1991. "Macroeconomic Adjustment to Oil Shocks and Fiscal Reform: Simulations for Zimbabwe, 1988-95." Policy Research Working Paper 772. World Bank, Country Economic Department, Washington, D.C. Processed.

1998. "Macroeconomic Policies, Instability, and Growth across Developing Regions." Joumal of African Economies (supplementary edition). Volume 7, Supplement 2: December; pp. 116-168.

Farzin, Y. H. 1990. "Optimal Saving and Investment Policies for the Petroleum-based Economy of the United Arab Emirates." World Bank, Washington, D.C. Processed.

Feldstein, Martin, and Phillipe Bacchetta. 1991. "National Saving and International Investment." In B. Douglas Bernheim and John Shoven, eds., National Saving and Economic Performance. Chicago: University of Chicago Press.

Feldstein, Martin, and Charles Horioka. 1979. "Domestic Savings and International Capital Flows." Economic Journal 90(3):314-29.

Fershtman, Chiam, and Yoram Weiss. 1993. "Social Status, Culture, and Economic Performance." Economic Joumal 103(July):946-59.

Gelb, Alan. 1985a. "Are Oil Windfalls a Blessing or a Curse? Policy Exercise with an Indonesia-Like Model.” DRD Discussion Paper 135, World Bank, Development Research Department, Washington, D.C. Processed.

. 1985b. "The Impact of Oil Windfalls: Comparative Statics with an IndonesiaLike Model." DRD Discussion Paper 133, World Bank, Development Research Department, Washington, D.C. Processed. 
Gordon, Roger, and Lars Bovenberg. 1994. "Why is Capital So Immobile Internationally? Possible Explanations and Implications for Capital Income Taxation." Working Paper 4796. NBER 4796:1-30.

Hadjimichael, Michael, and Dhaneshwar Ghura. 1995. "Public Policies and Private Savings and Investment in Sub-Sahara Africa: An Empirical Investigation." IMF Working Paper WP/95/19. International Monetary Fund, Washington, D.C. Processed.

Harrigan, Frank. 1995. "Saving Transitions in South East Asia." Department of Economics, University of Oxford, Processed.

Holtz-Eakin, Douglas, Whitney Newey, and Harvey S. Rosen. 1988. "Estimating Vector Autoregressions with Panel Data." Econometrica 56(6): 1371-395.

Hope, K. R. 1997. "Growth, Savings and Investment in Botswana." Savings and Development 21(2): 195-210.

Hope, K. R., and W. A. Edge. 1996. "Growth with Uneven Development: Urban-Rural Socio-Economic Disparities in Botswana." Geoforum 27(1).

King, Robert, and Ross Levine. 1994. "Capital Fundamentalism, Economic Development, and Economic Growth." Camegie Rochester Series on Public Policy 40(0):259-92.

Kwasa, Shadrack O. 1992. "Kenya." In J. H. Frimpong Ansah and Barbara Ingham, eds., Saving for Economic Recovery in Africa. London: James Curry.

Levine, Ross, and David Renelt. 1992. "A Sensitivity Analysis of Cross-Country Growth Regressions." American Economic Review 82(4):942-63.

Lucas, Robert E. Jr. 1988. "On the Mechanics of Economic Development." Journal of Monetary Economics 22(July): 22(1):3-42.

Masson, P. R., Tamim Bayoumi, and Hossein Samiei. 1995. "Saving Behavior in Industrial and Developing Countries." IMF Working Paper WP/95/51. International Monetary Fund, Washington, D.C. Processed.

McKinnon, Ronald. 1973. Money and Capital in Economic Development. Washington, D.C.: Brookings Institution.

- 1991. The Order of Economic Liberalization: Financial Control in the Transition to a Market Economy. Baltimore, Md.: Johns Hopkins University Press.

Moyo, Sam. 1996. “Trends of Savings in Financial Intermediaries in Zimbabwe." In J. H. Frimpong Ansah and Barbara Ingham, eds., Saving for Economic Recovery in Africa. London: James Curry.

Mwega, Francis M. 1996. "Saving in Sub-Sahara Africa: A Comparative Analysis." Paper presented at an African Economic Research Consortium (AERC) Plenary, Nairobi, May. Processed.

Mwega, Francis M., Njuguna Mwangi, and S. M. Ngola. 1990. "Real Interest Rates and the Mobilization of Private Savings in Africa: A Case Study of Kenya." AERC Research Paper 2. AERC, Nairobi. Processed.

Ndung'u, Njuguna. 1997. "The Impact of Financial Sector Liberalization on Savings, Investment, Growth, and Financial Development in Anglophone Africa." African Development Review 9(1):20-51.

Norberg, Helene, and Magnus Blomstrom. 1993. "Dutch Disease and Management of Windfall in Botswana." International Economics and Geography. 111:162-78.

Obstfeld, Maurice. 1995. "Effects of Foreign Resource Inflows on Saving: A Methodological Overview." World Bank, Washington, D.C. Processed.

Ostry, Jonathan D., and Carmen Reinhart. 1992. "Private Savings and Terms of Trade Shocks: Evidence from Developing Countries." IMF Staff Papers 39: 495-517. 
Rodrik, Dani. 1998. "Why Is Trade Reform So Difficult in Africa." Journal of African Economies 7(1): 43-69.

Roemer, Paul. 1986. "Increasing Returns and Long-Run Growth. "Joumal of Political Economy 94(5):1002-37.

Schmidt-Hebbel, Klaus, 1996. "Fiscal Adjustment and Growth: In and Out of Africa." Joumal of African Economies 5(3):7-59.

Schmidt-Hebbel, Klaus, and Luis Servén. 1996. "Saving and Investment: Paradigms, Puzzles, Policies." The World Bank Research Observer 11(1):87-117.

Schmidt-Hebbel, Klaus, Steven B. Webb, and Giancarlo Corsetti. 1992. "Household Saving in Developing Countries: First Cross-Country Evidence." The World Bank Economic Review 6(3):529-47.

Servén, Luis. 1997. "Irreversibility, Uncertainty, and Private Investment: Analytical Issues and Some Lessons for Africa." Journal of African Economies 6(3): 229-68.

Shaw, Edward. 1973. Financial Deepening in Economic Development. New York: Oxford University Press.

Solow, Robert. 1956. "A Contribution to the Theory of Economic Growth." Quarterly Journal of Economics 70(February): Vol. 70(1) pp. 65-94.

Summers, Lawrence. 1988. "Tax Policy and International Competitiveness." In Jeffrey Frankel, ed., International Aspects of Fiscal Policies. Chicago: University of Chicago Press.

Tobin, James. 1967. "Life-cycle Saving and Balanced Growth. "In William Fellner, ed., Ten Economic Studies in the Tradition of Irving Fisher. New York: John Wily and Sons.

Williamson, John. 1994. “The Washington Consensus Revisited.” In Louis Emmerij, ed., Economic and Social Development in the Twenty-First Century. "Baltimore, Md.: Johns Hopkins University Press.

World Bank. 1994. Adjustment in Africa: Reforms, Results and the Road Abead. New York: Oxford University Press.

Young, Alwyn. 1994. "The Tyranny of Numbers: Confronting the Statistical Evidence of East Asian Growth Experience." NBER Working Paper 4680. National Bureau of Economic Research, Cambridge, Mass. Processed.

Zou, Heng-Fu. 1993. "The Spirit of Capitalism, Savings, and Growth." World Bank, Development Research Group, Washington, D.C. Processed. 
